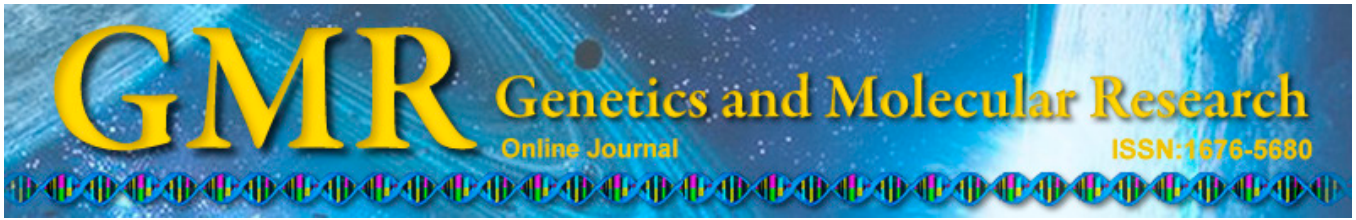

Thesis Abstract

\title{
Cytogenetic and protein quantification in polyploid somatic tissue of Myrmeleon uniformis (Neuroptera, Myrmeleontidae)
}

\author{
C.A. Pacheco, T.L. da Silva and M.K.H. Kobayashi \\ 2002. Instituto de Biociências, Letras e Ciências Exatas, \\ Universidade Estadual Paulista "Júlio de Mesquita Filho", \\ São José do Rio Preto, SP, Brasil \\ Master thesis. Orienting Prof.: M.K.H. Kobayashi \\ Corresponding author: T.L. da Silva \\ E-mail: lucenabio@hotmail.com
}

Genet. Mol. Res. 14 (2): 3877-3878 (2015)

Received March 27, 2014

Accepted April 8, 2015

Published April 27, 2015

DOI http://dx.doi.org/10.4238/2015.April.27.1

Myrmeleon unifomis Malpighian tubules cells were analyzed under two aspects: chromatin structure and total protein quantification in the three larval phases $\left(\mathrm{L}_{1}, \mathrm{~L}_{2}\right.$ and $\left.\mathrm{L}_{3}\right)$ and in adults. This insect Malpighian tubules present polyploid tissue resultant from endoreduplication, which probably begins in the first larval phases. The Malpighian tubule proximal region in $\mathrm{L}_{2}, \mathrm{~L}_{3}$ and adult cells has polyploid nuclei, although the polyploid degree does not cause change in its morphology; nevertheless in the $\mathrm{L}_{3}$ larvae distal region, polyploidization changes the cell morphology from a round to a multilobulate shape. Chromatin analysis in these nuclei by cytochemical techniques showed that the whole nucleus is filled out with a granular chromatin. In multilobulate nuclei during $\mathrm{L}_{3}$ the chromatin is formed by a network of chromatin fibers. The nucleolar markings made in the several development phases of Myrmeleon sp showed the gradual increase that occurs during the larval phases and their reduction in the adult phase. This transcriptional activity was confirmed by total protein analyses, which were quantified by SDS-PAGE. The 39.8-kDa band deserves prominence, because it can be seen 
from $\mathrm{L}_{2}$ phase, increasing its intensity during $\mathrm{L}_{3}$ and decreasing in the adult phase, indicating that this protein is related to production of the pupation cocoon.

Key words: Polyploidy; Endoreduplication; Malpighian tubules; Chromatin; Neuroptera; Antlion 